\title{
RUSSIA'S ROLE IN AFGHAN PEACE PROCESS
}

\author{
Aamir Junaid \\ Visiting Lecturer, \\ Department of International Relations \\ Government College University \\ Faisalabad-Pakistan \\ Dr. Ghulam Mustafa \\ Assistant Professor \\ Department of International Relations \\ Government College University \\ Faisalabad - Pakistan \\ ghulammustafa@gcuf.edu.pk \\ Umm-e-Rubab \\ Visiting Lecturer \\ Department of International Relations \\ Government College University \\ Faisalabad - Pakistan
}

\begin{abstract}
Kabul has tremendous importance in Moscow's strategic culture. Moscow has seen Kabul as a place for competition with the western world. Russia has fought in Afghanistan in the 1980s with different segments of Afghan society. After the complete silence of more than two decades, Russia has now started to take an interest in the internal politics of Afghanistan directly. Moscow has established strong ties with the political identities of Afghanistan. Russia has also found links with the Taliban in Afghanistan. America has also blamed Russia for supporting the Taliban militants against American and NATO forces in Afghanistan. Moscow hosted the Intra Afghan Talks in 2019 before starting the official peace process between America and the Taliban. Moscow now fully supports the initiatives has taken by the United States; Moscow wants a significant role in Afghanistan after the American withdrawal. Washington and Moscow are not on the same page on different issues, but both states are willing to bring peace to Afghanistan.
\end{abstract}

Keywords: Russia, America, Taliban, Afghanistan, Militants 


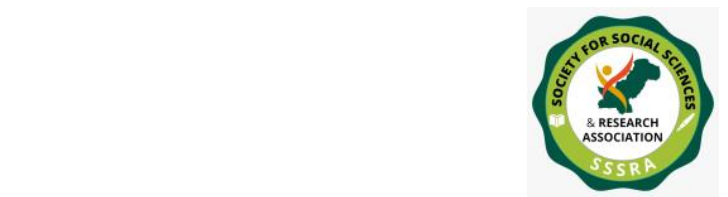

Pak. Journal of Int'L Affairs, Vol 4, Issue 4 (2021)

Russia's Role in Afghan Peace Process...

\section{Introduction}

Moscow has always seen Kabul from the lens of security. Russia does not want disturbance on the border region among Afghanistan and the Central Asian States. Tajikistan, Kyrgyzstan and Kazakhstan are part of the Collective Security Treaty with Russia (Aliyev, 2020). Moscow wants to prevent Afghanistan from becoming a launching pad by other powers, especially the United States and other western allies. Afghanistan's geography enhances its importance worldwide. Russia wants to play its role in Eurasia by using the geography of Afghanistan. Instead of the security sphere, Russia does not have other economic benefits from Afghanistan as India and other states like Iran and Pakistan have in Afghanistan. New Delhi, Tehran and Islamabad want access to the Central Asian States. The CARs have an abundance of energy resources. New Delhi wants to get these resources of CARs through Kabul. India can quickly access CARs, including Russia, through Afghanistan (Mustafa, Junaid, Khan, \& Wakil, 2020). Moscow has different intentions from Tehran and New Delhi. Now Russia is keen on the internal politics of Afghanistan and enhances its ties with political and militant's groups in Afghanistan.

Moscow is keeping an eye on the peace deal between America and the Taliban. According to the peace agreement, America will withdraw its forces from Afghanistan. The Taliban will cut its ties with other terrorist groups and does not allow the use of Afghanistan's soil against America. Challenges are severe on the way to peace in Afghanistan. Russia wants to fill the vacuum after American withdrawal and is hopeful of mending its ties with Afghanistan's people and other groups. In 2014 Kremlin has changed its policy towards Afghanistan and starting to take an interest in the internal politics of Afghanistan. Russia does not want to allow Islamic State Khorasan Province (ISKP) to get a stronghold in Afghanistan. Extremist activities in Afghanistan and the other Central Asian states spill over Moscow (Gohel \& Bailey, 2020). After the peace deal between America and the Taliban, Russia and United States issued a clear statement that both parties would not accept the Taliban's Emirate model of government in Afghanistan. Moscow's interactions with the Taliban leaders indicate that Russia considers a significant stakeholder to the Taliban. However, America and Russia stressed the Taliban to cut its ties with Al Qaeda and other terrorist groups working in Afghanistan against others (Iqbal, 2020). Russia is very keen to bring peace to Afghanistan and appreciates the peace deal between the United States and the Taliban.

\section{Research Methodology}

The researcher tried to get data from existing literature and the researcher visited different institutions to get relevant data to complete his research paper. Different dignitaries helped 


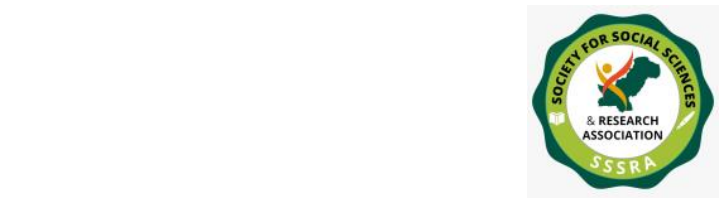

Pak. Journal of Int'L Affairs, Vol 4, Issue 4 (2021)

Russia's Role in Afghan Peace Process...

the researcher complete his research work-libraries of different universities visited to get maximum data. The researcher tried his best to find data from online journals and websites. Books, newspapers and electronic media were used to obtain relevant data. The researcher approached the personalities from academia to get maximum knowledge about this topic to complete his research paper.

\section{Literature Review}

The Great Gamble: The Soviet War in Afghanistan by Gregory Feifer explains the Soviet adventure in Afghanistan. The author considers the Afghan-Soviet war an important event in the demise of the USSR. The author also puts light on the emergence of the Mujahedeen in Afghanistan. During the war, different groups emerged in Afghanistan in the name of Jihad and the writer explains them in his book. Afghanistan has a long history of wars and the author noted it well in his work (Feifer, 2010).

Persistence and Change in Soviet and Russian Relations with Afghanistan by Andrei Dorre and Tobias Kraudzun explores the development projects during Soviet time and policy changes in Russia's time. The writers express in detail the flagship projects of the Soviet Union in Afghanistan before the Soviet-Afghan war in 1979. Kremlin has supported the Afghanistan government in security and economic activities. The authors have described Moscow's aim to help Afghanistan in the Soviet Union and in present times. The writers elaborate on the real threats for Russia in the region and the first threat is the transportation of drugs via Russia to Europe. The second one is the increase in Islamist activities in the Central Asian states and destabilization in Afghanistan. According to the writers, Moscow wants to increase its influence in Afghanistan to counter the western narrative by using soft power (Dorre \& Kraudzun, 2012).

Afghanistan's Significance for Russia in the $21^{\text {st }}$ Century: Interests, Perceptions and Perspectives by Kaneshko Sangar elaborates the Afghanistan's importance due to its geographic and geostrategic location in international politics. Russia always tried to dominate world politics, but American presence in the neighborhood creates problems for Russia. Russia has significant concerns about the NATO presence in Afghanistan. Moscow wants to minimize the role of America in the South and Central Asian region. The writer focuses on Russian relations with the Central Asian States and Afghanistan. Russia does not want to lose its grip on the Central Asian Republics. Still, militancy in Afghanistan and the increase in Islamist groups in CARs are the real threat to Russian security. Moscow is keen to enhance its influence in the Central Asian States and Afghanistan through soft power. Moscow is interested in different projects to secure its reach to Kabul and the Central Asian states (Sangar, 2016). 


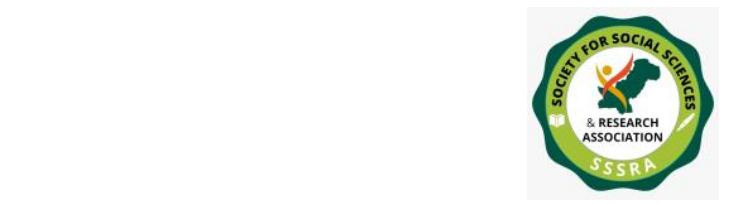

Pak. Journal of Int'L Affairs, Vol 4, Issue 4 (2021)

Russia's Role in Afghan Peace Process...

Russian Returns to Afghanistan: Prospects of Bilateral Economic Cooperation by Asef $\mathrm{N}$ explains the economic situation of Afghanistan right after the demise of the Taliban regime. The writer also focuses on the trade relations between Moscow and the Kabul regime. Russia has a long history of relations with the Taliban regime. Kremlin often helped Afghanistan in the past and the present. Moscow supported the Afghanistan government to build infrastructure and boost its economy in the past. The writer explains the Russian intentions towards Afghanistan. Kabul has a poor economy and the long civil war has ruined the infrastructure of Afghanistan. Kremlin is considering it a vital chance to get into Afghanistan and improve its image in society through soft power. The writer highlights the chances to improve ties between Russia and Afghanistan through trade and security cooperation (N, 2017).

Russia and the Search for a Negotiated Solution in Afghanistan by Ekaterina Stepanova elaborate on the diplomatic role of Russia in Afghanistan. The writer shows the importance of Moscow in the Afghan political circles. In the first quarter of 2019, the Anti-Taliban forces visited Moscow and discussed the internal situation of Afghanistan with the Russian leadership. It was a significant development because America already has started direct talks with the Taliban in the capital city of Qatar in September 2018. It shows the Kremlin's intentions in Afghanistan after the withdrawal of United States forces. The writer highlights Russian foreign policy changes its significant diplomatic role in Afghanistan (Stepanova, 2020).

\section{Research Questions}

1. What is the role of Russia in the Afghan Peace Process?

2. Why is Moscow so keen on Afghanistan's internal security?

\section{Role of Russia in Afghan Peace Process}

After 1991 Russian policy towards Afghanistan was very clear that Russia would never take part in internal Afghan politics. The incident of 9/11 changed the whole dynamics of world security. America toppled the Taliban regime right after the incident of 9/11 in 2001 . Russia considered it right and welcomed this American move to Afghanistan. America also assured Russia that it would eliminate the fighters who belonged to Chechnya and other Islamist terrorists posed a threat to Russian national security. It was beneficial for both countries to accept their reservations (Rafiq, 2017). Russia was always in favor of eliminating the safe havens of terrorist groups working in Afghanistan. Kremlin always considered it a threat for itself and the Central Asian States. It was alarming for Russia that Chechen President Zalim Khan visited Afghanistan and Islamabad. Russia was not in favor 


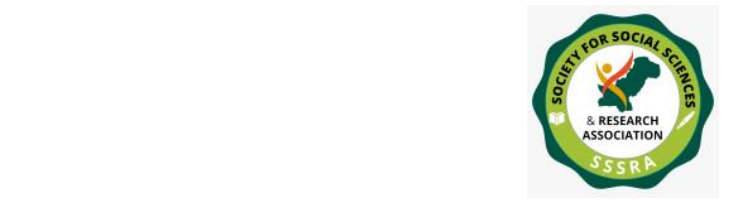

Pak. Journal of Int'L Affairs, Vol 4, Issue 4 (2021)

Russia's Role in Afghan Peace Process...

of the Taliban style of government. Moscow always considered the Taliban a threat to growing Islamization in the region. The tour of Zalim Khan to Islamabad and Kabul and the acceptance of Chechnya as an independent state was alarming for Moscow (Clark, 2000).

With time, things have changed; America and its allies are accusing Moscow of providing weapons and bounties to the Taliban. United States thinks Moscow is involved in the killings of the American and NATO soldiers in Afghanistan. A Russian official in Kabul has accepted that Russia contacts the Taliban to save its citizens from damaging American interests (Sputnik, 2017). Moscow now has established friendly relations with all neighboring states of Afghanistan. Russia also has connections with the political identities of Afghanistan. Moscow started an initiative to conduct talks with neighboring countries of Kabul to bring peace in Afghanistan in 2016 (Ibrahimi, 2018).

A multi-lateral meeting was held and the Taliban were also invited despite Afghan government reservations in 2018. It was a reasonable effort from regional powers to bring peace to Afghanistan and it shows the commitment of the neighboring states to bring durable peace in Kabul (Roth, 2018).

All major players, especially western powers, did not expect Russia's significant role to bring peace to Kabul. Many prominent dignitaries from Afghanistan have participated in those talks held in Russia in 2019. Many prominent political figures, including Hamid Karzai, Mohammad Mohaqiq, and Yunus Qanuni, have experienced. The most important thing was the participation of women parliamentarians in those talks (Jung \& Cobar, 2019).

The complicated thing was the response of the Afghan government towards these talks. The Afghan government did not participate in those talks. Afghan government questioned the legitimacy of the participants (Salahuddin, 2019). Different meetings have been held for many years to bring peace to Afghanistan, and all regional players are playing their roles in the Afghan peace process. China and Iran are also trying to engage different segments of Afghan society and Pakistan. Iran and China have linkages with the Taliban militants in Afghanistan and the Taliban leaders often visited Beijing and Tehran in the recent past (Mustafa, Ahmad, \& Junaid, 2020). But the Moscow meeting was unique because all the members of Afghan society were gathered under one roof in Russia. It was the first time that Taliban leaders and Afghan leaders were gathered for peace talks and this meeting was publically announced. In the beginning, Taliban leaders and Afghan leaders talked openly about the future framework of Afghanistan. The most exciting thing was the idea of the interim government. President Ashraf Ghani always opposed the idea 


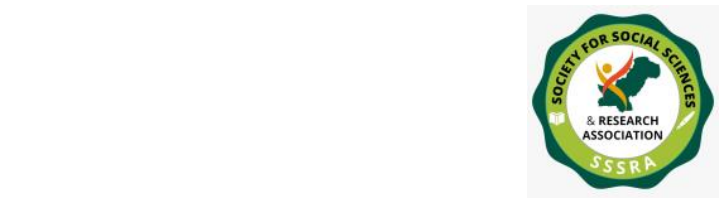

Russia's Role in Afghan Peace Process...

of a provisional government in Afghanistan while all Afghan leaders and the Taliban agreed on the idea of interim government; this was an exciting development in the politics of Afghanistan (Aljazeera, 2019).

After the Moscow talks, one thing has cleared the Taliban are no more in isolation. Taliban are reaching out to all other segments and political identities in and out of Afghanistan. Taliban are showing willingness towards alliances in the political scene of Afghanistan. Moscow talks also cleared that the Taliban's stance on withdrawal of foreign forces, interim government, and making changes in the Afghan constitution is gaining strength (Langari, 2019).

The importance of Moscow talks was also seen for the future political setup of Afghanistan. It was a platform for making new alliances in the future politics of Afghanistan. Russia provided a platform for all stakeholders of Afghanistan (Revell, 2019). After 18 years of war, the US could not get its desired objectives in Afghanistan. America cannot defeat the Taliban with weapons. Taliban now controls more territory than before. Now America has changed its policy towards Afghanistan. The United States does not want to continue the Afghan war anymore. America wants to keep an eye on Russia and China rather than fight Afghanistan. Now America has more focused on Russia and China than terrorism (Lange, 2018).

During the Obama era America has minimized its military presence in Afghanistan. Obama announced that the world is now better positioned than earlier insecurity. America will focus security of Afghanistan and assist Afghan forces with the minimum presence of its military in Kabul (The White House, 2014).

President Trump also took such steps to minimize its presence in Afghanistan. Now Afghan political parties have changed their politics. A large number of political parties except the Afghan government were agreed on withdrawal from foreign forces. They also announced Afghan soil would not be used against any other country and in return, neighboring states should avoid interfering in the internal politics of Afghanistan. The most exciting thing about the Russian Soil Afghan parties in the presence of the Taliban announced that Afghan women are an essential part of Afghan society and women have a significant role to play in the internal politics of the society. The international community should come forward to play its part in the reconstruction of Afghanistan (Sputnik, 2019).

Russia plays a vital role in peace in Afghanistan. Afghan government of Ashraf Ghani is continuously criticizing the participants and the hosting authorities. President Ghani called them attention seekers who participated in Moscow talks. President Ghani thinks peace 


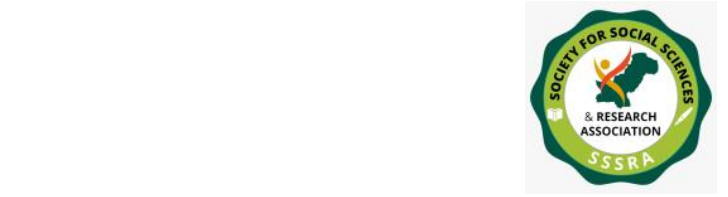

Russia's Role in Afghan Peace Process...

cannot prevail in war-affected Afghanistan (Salaam Times, 2019). The most important thing is the new role of Russia in Afghanistan. Russia is talking with the Afghan leaders and engaging regional players as well. The presence of the Islamic State in Khorasan Province is a real worry for Russia. To eradicate ISKP, Moscow is talking with all Afghan stakeholders and the neighboring states of Afghanistan. Russia has done what America could not do in the past. Intra Afghan talks in Moscow were an extensive development towards peace in Afghanistan. Some spoilers are also trying to derail this peace process. Russia wants to eradicate SKP from Afghanistan in front of the Central Asian neighboring states of Moscow (Wojcik, 2018).

America wants to withdraw its forces from Afghanistan till the May of 2021. Now America has changed its policy towards Russia and America coordinating with Russia about Afghan peace efforts. It's a significant change in American policy towards Russia. Once America had accused Russia of supporting Taliban militants against American troops. America's attitude towards Russia is considered positive for peace purposes in Afghanistan (Sheikh, 2019).

Moscow has hosted many rounds of talks with the Taliban; President Putin has helped President Trump withdraw its forces from Afghanistan. Trump suspended talks with the Taliban in September 2019, then Russia came forward and offered to act as a guarantor between the Taliban and America. It shows Russia's commitment to peace in Afghanistan (Ramani, 2019).

Russia welcomed a peace deal between America and the Taliban in Doha in February 2020. Russia warned that Moscow would not accept the complete hold of the Taliban in the country and Russia also welcomed the Taliban's statements regarding political settlement in Afghanistan. Moscow appreciated Taliban efforts towards the reduction of violence in the country. Moscow also stresses on all the country's stakeholders to come forward and work together to better the country (Tolo News, 2020).

Like all other countries of the region, Russia also wants peace on its terms in Afghanistan. Peace in Kabul benefits all neighboring states, including Russia.

\section{Conclusion}

Russia considers Afghanistan a critical state in the context of security. Moscow is very keen to bring durable peace to Afghanistan because militant activities in Afghanistan have a spillover effect on the Central Asian states, which harms Kremlin's security. Russia is worried about the drug trafficking from Afghanistan to Europe via Russia. Russia wants to 
stop this at any cost because the Russian youth is getting prey to it. Moscow has concerned about militant activities in Afghanistan. The central Asian States have different militant organizations and militancy in Afghanistan provides them safe havens for all those militant groups. Russia supports the Afghan peace process to eradicate the safe heavens of militants in Afghanistan. Moscow now has deep connections with all political identities in Afghanistan. Russia wants peace in Afghanistan but does not want to control the Taliban. Russia thinks the Talibanization in Afghanistan is harmful to the South and Central Asian region. Peace is the only solution for a prosperous Afghanistan and Russia is the biggest beneficiary with Pakistan if peace prevails in Afghanistan. 


\section{References}

Aliyev, N. (2020, 19 October). How Russia Views Afghanistan Today. Retrieved from War On The Rocks: https://warontherocks.com/2020/10/russias-contemporary-afghanpolicy/

Aljazeera. (2019, 6 February). Taliban, Afghan opposition hold Moscow talks without government. Retrieved April 2020, from Aljazeera:

https://www.aljazeera.com/news/2019/02/taliban-afghan-opposition-hold-moscowtalks-government-190205135737423.html

Clark, K. (2000, 21 January). Chechnya to open Kabul embassy. Retrieved April 2020, from BBC News: http://news.bbc.co.uk/2/hi/south_asia/613764.stm

Dorre, A., \& Kraudzun, T. (2012). Persistence and change in Soviet and Russian relations with Afghanistan. Central Asian Survey, 31(4), 425-443.

Feifer, G. (2010). The Great Gamble: The Soviet War in Afghanistan. New York: Harper Perennial.

Gohel, S. M., \& Bailey, A. (2020, 1 July). This Time, Russia Is in Afghanistan to Win. Retrieved from Foreign Policy: https://foreignpolicy.com/2020/07/01/russiaafghansitan-united-states-bountygate/

Ibrahimi, S. S. (2018, 2 November). Can Russia Help Bring Peace to Afghanistan? Retrieved April 2020, from Center on International Cooperation: https://cic.nyu.edu/news/Can-Russia-Help-Bring-Peace-to-Afghanistan

Iqbal, A. (2020, 9 March). US, Russia not to accept 'Islamic emirate' in Afghanistan. Retrieved from Dawn: https://www.dawn.com/news/1539436

Jung, Y., \& Cobar, J. F. (2019, 7 March). Unpacking the Afghan peace talks: Inclusion of women in the process and achieving durable peace. Retrieved April 2020, from Stockholm International Peace Research Institute: https://www.sipri.org/commentary/blog/2019/unpacking-afghan-peace-talksinclusion-women-process-and-achieving-durable-peace 
Langari, S. Z. (2019, 6 February). Joint Declaration Issued After Moscow Talks. Retrieved April 2020, from Tolo News: https://tolonews.com/afghanistan/joint-declarationissued-after-moscow-talks

Lange, K. (2018, 8 October). What Is the National Defense Strategy? Retrieved April 2020, from US Department of Defence:

https://www.defense.gov/Explore/Features/story/Article/1656414/what-is-thenational-defense-strategy/

Mustafa, D. G., Ahmad, D. M., \& Junaid, A. (2020). China and Iran's Role in Afghan Peace Process. Sir Syed Journal of Education \& Social Research, 3(4), 424-432.

Mustafa, D., Junaid, A., Khan, R. B., \& Wakil, I. (2020). India's Role in Afghan Peace Process. Journal of Political Studies, 27(2), 129-140.

N, A. (2017). Russia Returns to Afghanistan: Prospects of Bilateral Economic Cooperation. Vestnik Rudn. International Relations, 17(4), 781-792.

Rafiq, A. (2017, 12 January). Russia Returns to Afghanistan. Retrieved April 2020, from The National Interest: https://nationalinterest.org/feature/russia-returns-afghanistan19040

Ramani, S. (2019, 11 September). In the Demise of the Taliban Peace Talks, Russia Is the Winner. Retrieved April 2020, from Foreign Policy:

https://foreignpolicy.com/2019/09/11/in-the-demise-of-the-taliban-peace-talksrussia-is-the-winner/

Revell, P. (2019, 6 February). Taliban and senior Afghan politicians hold talks in Moscow, upsetting the government. Retrieved April 2020, from Abc News:

https://abcnews.go.com/International/taliban-senior-afghan-politicians-hold-talksmoscow-upsetting/story?id=60852053

Roth, A. (2018, 9 November). Russia hosts talks between the Taliban and the Afghan peace council. Retrieved April 2020, from The Guardian:

https://www.theguardian.com/world/2018/nov/09/russia-hosts-talks-between-talibanand-afghan-peace-council

Salaam Times. (2019, 6 February). Moscow meeting has no bearing on Afghan-Taliban peace process: Ghani. Retrieved April 2020, from Salaam Times: 
https://afghanistan.asia-

news.com/en_GB/articles/cnmi_st/features/2019/02/06/feature-01

Salahuddin, S. (2019, 4 February). Afghan government frozen out of Moscow peace talks with the Taliban. Retrieved April 2020, from The Washington post: https://www.washingtonpost.com/world/afghan-government-frozen-out-of-moscowpeace-talks-with-the-taliban/2019/02/04/b9670c46-286a-11e9-8eef0d74f4bf0295_story.html

Sangar, K. (2016). Afghanistan's significance for Russia in 21st Century: Interests, Perceptions and Perspectives. Politics in Central Europe, 12(1), 59-82.

Sheikh, S. R. (2019, 5 May). Russia: the New Center of Afghan Peace Process? Retrieved April 2020, from New Eastern Outlook: https://journal-neo.org/2019/05/05/russiathe-new-center-of-afghan-peace-process/

Sputnik. (2017, 10 March). Moscow Reveals Its Aims in Contacts With Outlawed Taliban in Afghanistan. Retrieved April 2020, from Sputnik:

https://sputniknews.com/asia/201703101051447846-russia-taliban-relations/

Sputnik. (2019, 8 February). Karzai on 'Intra-Afghan' Summit: Talks in Moscow Exceeded All Our Expectations. Retrieved April 2020, from Sputnik:

https://sputniknews.com/interviews/201902081072254085-afghanistan-moscowtalks-karzai/

Stepanova, E. (2020). Russia and the Search for a Negotiated Solution in Afghanistan. Europe-Asia Studies, 1-25. doi:DOI: 10.1080/09668136.2020.1826908

The White House. (2014, 28 December). Statement by the President on the End of the Combat Mission in Afghanistan. Retrieved April 2020, from The White House: https://obamawhitehouse.archives.gov/the-press-office/2014/12/28/statementpresident-end-combat-mission-afghanistan

Tolo News. (2020, 7 March). US, Russia: 'Will Not Support' an 'Islamic Emirate in Afghanistan. Retrieved April 2020, from Tolo News:

https://tolonews.com/index.php/afghanistan/us-russia-will-not-support-islamicemirate-afghanistan 
Wojcik, P. (2018, 31 July). Turning east: the rise of Islamic State's Khorasan Province. Retrieved April 2020, from The Defence Post:

https://www.thedefensepost.com/2018/07/31/afghanistan-isis-khorasan-province/ 